\section{A Cursory Marketing Analysis of Faculty Book Ordering}

\author{
Stephen K. Johnson
}

Stephen K. Johnson is the business and public policy librarian at the University of South Dakota.

Correspondence concerning this column should be addressed to Marianne Ryan, Dean of Libraries, Loyola University Chicago, 1032 W. Sheridan Road, Chicago, IL 60660; email: mryan21@/uc.edu.
Library liaisons can have full plates, as they juggle instruction, outreach, and collection development responsibilities in their work with academic departments. A challenge of these roles can be engaging faculty as partners. In this column, Stephen K. Johnson describes his effort to enlist faculty in the book-ordering process. He explains the creative approach he took and the results derived-along with why it matters._Editor

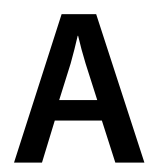

$\mathrm{s}$ the business and public policy librarian for the University of South Dakota (USD), I am the department liaison to five academic departments on the USD campus. USD identifies itself as the comprehensive liberal arts institution for the state of South Dakota. Its enrollment is approximately 10,200 students: 75 percent undergraduate, 25 percent in graduate programs. Online offerings continue to grow significantly, particularly in areas with a professional emphasis_-such as business or nursing - which attract students from around the world. In addition to undergraduate programs, USD offers graduate degrees in approximately sixty-five different areas, a dozen of which are doctoral granting. USD also has an array of professional programs: a medical school with specialties in rural health and primary medical care, a law school, a school of health sciences (for nursing, social work, physical and occupational therapy, medical laboratory sciences, alcohol and drug studies, and physician assistant training), and the aforementioned business school. ${ }^{1}$ And, as with most colleges and universities, the research expectations for our faculty have become more stringent during the past decade.

My focus in this column is on examining faculty-initiated book ordering - in both hard-copy and online formatsin the five departments I support: the Beacom School of Business in its entirety, the (merged) Political Science and Criminal Justice Department, the Psychology Department (comprising two components: counseling and human factors), and the Educational Leadership Division, a graduateonly program targeted to $\mathrm{K}-12$ school administrators and administrative employees involved in higher education. I will examine whether senior-level faculty members are more likely to engage in book ordering than their junior- and midlevel teaching faculty counterparts.

\section{PREVIOUS STUDIES}

Faculty book-ordering practices appear to have become a dormant research topic in the last nineteen years since 


\section{MANAGEMENT}

Hui-Min (2000) described Kean University Library's practices. ${ }^{2}$ Similar that of USD's library, Kean's approach of having faculty submit new book orders is a long-standing practice. At both institutions, each academic department on campus is allocated a percentage of the library's book budget. Every faculty member is encouraged to submit book requests through a person designated by the respective academic departments, working in conjunction with the librarian assigned to that department. Every book is ordered immediately, presumably until the department's book budget is exhausted. Hui-Min's study also analyzed faculty involvement in Kean University's overall collectiondevelopment efforts.

In a 1986 study that foreshadowed Hui-Min's work, forty classroom faculty members from colleges throughout Indiana were interviewed by Hardesty to determine their attitudes involving library book-selection efforts. Hardesty's findings indicated that college library faculty lacked a welldeveloped thought process about relevant material for an undergraduate-oriented library. ${ }^{3}$ Similarly, in articles published in 1995 and 1997, Chu interviewed faculty members at Illinois State University and concluded that cooperation between departmental faculty and librarians must be a "twoway street" for it to be an effective process. ${ }^{4}$

\section{MY APPROACH}

My own strategic intent for working collaboratively with the faculty in my assigned departments is to model my liaison work after that of account executives, similar to those I once worked with in the group division of a large life and health insurance company. These were individuals who worked exclusively with companies such as Cargill, Chrysler Corporation, Gerber Foods, and Kellogg's Cereals. The analogy helps me define and focus what I do from the standpoint of troubleshooting or problem solving. I also need to have an instinctive grasp of the needs of both faculty and students within my five academic departments, much as insurance account executives needed with respect to their corporate accounts. Trends, particularly involving students, frequently change. A liaison has to be acutely aware of such developments, and so I strive to learn all I can about each department without being intrusive. Being cognizant of the pressures that today's faculty members face is essential to my work. This mix creates challenges that tap my creativity and energize me in my work.

My interest in examining book ordering in relation to the seniority of the faculty submitting orders stems from something peculiar that happened when I weeded the psychology collection over an eight to nine month period in 2012. For the titles I proposed weeding, I exported records from our online library catalog (at the time, ALEPH) into an EndNote file. ${ }^{5}$ Those titles were sent through e-mail to the department's sixteen faculty members at no more than twenty-five entries per message. The eight out of sixteen total faculty members who had been at USD more than twenty years frequently responded about titles that might be classics in their area and therefore were not a candidate for weeding. My intuition told me that this more senior group actually enjoyed the process. I also found that their level of trust in me as department liaison appeared to increase. What seemed strange about this weeding project is that I never heard from the eight remaining faculty, who were more junior. I mentioned this at a meeting with our reference librarians. A particularly insightful colleague, now retired, wondered if the great book works in a given field are no longer emphasized in graduate-school seminars.

As a result of this experience and others over the past six years, I developed a significant concern that senior-level faculty members might be doing the bulk of departmental book ordering. I also worried that my mid-level and junior faculty members might be oblivious to the importance of academic press books in a university library. As the population born during the baby boom years will largely be retiring over the next decade, I needed to discover and quantify whether senior-level faculty members were doing most of the faculty book ordering in my departments. If so, what happens with USD's book collection for these five departments when these faculty retire?

\section{DEFINING THE FACULTY}

For purposes of this study, senior faculty members are defined as those who have been engaged in college teaching for more than fifteen years, mid-level faculty for eight to fifteen years, and junior-level faculty for fewer than eight years. USD uses the traditional faculty ranks of full professor, associate professor, assistant professor, and instructor. ${ }^{6}$ For many reasons, a number of faculty members are now being hired with lecturer status or with visiting or fixedterm appointments. The breakdown by faculty rank in my five departments in the 2017-18 academic year is shown in table 1 .

When I initially devised this study, I thought I would examine the book-ordering practices of these faculty members by generational labels (i.e., the "silent generation" born prior to 1943, "baby boomers" born between 1943 and 1960, "Generation X" born between 1961 and 1981, and "millennials" born between 1982 and 1996). ${ }^{7}$ Faculty vitae available on USD's departmental web pages appeared to provide me with the requisite information, since they include the year each the faculty member graduated from college as an undergraduate. Assuming faculty members were twenty-two years old when they finished college as undergraduates, they could be assigned one of the generational labels. That turned out to be a flawed assumption. For example, I discovered that one faculty member had graduated from college eleven years after finishing high school. There also were several faculty members who enlisted in the US military right out of high school. Other faculty members had previous careers 
Table 1. Faculty in five departments (2017-18 academic year) by rank

\begin{tabular}{|c|c|c|c|c|c|c|}
\hline Department & $\begin{array}{c}\text { Total } \\
\text { Faculty }\end{array}$ & $\begin{array}{c}\text { Full } \\
\text { Professor }\end{array}$ & $\begin{array}{l}\text { Associate } \\
\text { Professor }\end{array}$ & $\begin{array}{l}\text { Assistant } \\
\text { Professor }\end{array}$ & Instructor & $\begin{array}{l}\text { Lecturer } \\
\text { or Visiting } \\
\text { Professor }\end{array}$ \\
\hline Business School & 38 & 6 & 10 & 13 & 7 & 2 \\
\hline Political Science and Criminal Justice & 14 & 4 & 5 & 4 & - & 1 \\
\hline Psychology & 15 & 7 & 5 & 3 & - & - \\
\hline Educational Leadership & 8 & 2 & 2 & 2 & - & 2 \\
\hline Total & 75 & 19 & 22 & 22 & 7 & 5 \\
\hline
\end{tabular}

Table 2. Approximate breakout for the seventy-five faculty members if generational labeling were used

\begin{tabular}{lccccc}
\hline Department & Total Faculty & $\begin{array}{c}\text { Silent } \\
\text { Generation }\end{array}$ & Baby Boomers & Generation X & Millennials \\
Year of Birth & & pre-1943 & $1943-1960$ & $1961-1981$ & $1982-1996$ \\
\hline Business School & 38 & - & 11 & 18 & 9 \\
Political Science and Criminal Justice & 14 & - & 2 & 9 & 3 \\
Psychology & 15 & 1 & 6 & 3 & 3 \\
Educational Leadership & 8 & - & 23 & 35 & 1 \\
Total & 75 & 1 & & & 3 \\
\hline
\end{tabular}

Table 3. Classification for the seventy-five faculty members by number of years of teaching

\begin{tabular}{lcccc}
\hline Department & Total Faculty & Senior Faculty & Mid-Level Faculty & \multicolumn{1}{c}{ Junior Faculty } \\
Years of Teaching & & $15+$ years & $8-15$ years & $0-7$ years \\
Business School & 38 & 10 & 9 & 19 \\
Political Science and Criminal Justice & 14 & 6 & 3 & 5 \\
Psychology & 15 & 11 & 1 & 3 \\
Educational Leadership & 8 & 4 & 14 & 3 \\
Total & 75 & 31 & & 30 \\
\hline
\end{tabular}

as military officers, in private industry, or as K-12 school administrators.

Exceptions such as these made me uncomfortable with a generational framework for my study, but for the sake of comparison I compiled a "best guess" as to how the faculty would break out generationally (see table 2).

Having settled on the aforementioned framework for classifying faculty members by the duration of their college-level teaching, the breakdown for the study is shown in table 3.

\section{OVERVIEW OF USD'S COLLECTION DEVELOPMENT}

USD's collection development apparatus is largely driven by faculty book orders. The $\$ 152,000$ budget line that USD has for its book collection is approximately 3 percent of the library's total operating budget (which includes salaries and benefits for every library employee). Each department on campus is allocated a percentage of this amount, with most of it being derived from a formula that has been in place longer than the twenty-five years that I've been at USD. While I recognize the importance of journal literature, I also want to help develop a vibrant and up-to-date academic press book collection, and I want that material to be utilized by students in their research. My colleagues and I are responsible for assigning Library of Congress subject headings to the doctoral dissertations and master's and honors theses from the departments with which we work. All too frequently, I see virtually no monographs cited in the reference pages of those theses.

Some faculty members are always enthusiastic about submitting book orders, while others submit infrequently. I still feel that my efforts are a good way to keep open the lines of communication with them. I have had a number of bibliographic instruction opportunities with faculty members who sporadically submit orders, but for still others, I receive virtually no book orders. My working theory is that book 


\section{MANAGEMENT}

Table 4. Typical example of a book availability notice sent to department faculty

\begin{tabular}{|c|c|c|}
\hline Title & $\begin{array}{l}\text { Reporting Quantitative Research in } \\
\text { Psychology: How to Meet APA Style Journal } \\
\text { Article Reporting Standards }\end{array}$ & $\begin{array}{l}\text { Skill Development in Counselor Education: A } \\
\text { Comprehensive Workbook }\end{array}$ \\
\hline Author & Cooper, Harris M. & \\
\hline Editor & & Joy S. Whitman \\
\hline Publisher & Amer Psychological Assn & Routledge \\
\hline Year Published & 2018 & 2019 \\
\hline ISBN & 9781433829376 & 9781138695542 \\
\hline Binding & Paper & Cloth \\
\hline Library of Congress Subject Headings & Psychology--Authorship--Style Manuals. & Counselors--Study and Teaching. \\
\hline $\begin{array}{l}\text { Where the Author Is from or Something } \\
\text { Else about This Book }\end{array}$ & Auth: Duke University. & Ed: Northwestern University. \\
\hline Net Price & $\$ 24.56$ & $\$ 114.80$ \\
\hline
\end{tabular}

Table 5. Access file for book order requests from faculty members

\begin{tabular}{|c|c|c|c|c|c|c|c|}
\hline \multicolumn{2}{|l|}{ Book Title } & ISBN & \multicolumn{2}{|c|}{$\begin{array}{l}\text { Individual } \\
\text { Making Request }\end{array}$} & \multicolumn{2}{|c|}{$\begin{array}{l}\text { Date Faculty Member } \\
\text { Made Request }\end{array}$} & Dept. \\
\hline \multicolumn{2}{|c|}{ Graphics for Statistics and Data Analysis with R [2nd Edition] } & 9781498779838 & {$[\mathrm{Nal}$} & he omitted] & 22-Jun- & & BADM \\
\hline \multicolumn{2}{|c|}{ Salafism in Lebanon: Local and Transnational Movements } & 9781108426886 & {$[\mathrm{Nar}$} & he omitted] & 18-Jun- & & POLS \\
\hline Department & $\begin{array}{c}\text { Total Faculty Books } \\
\text { Purchased }\end{array}$ & $\begin{array}{l}\text { Fiscal } 2016 \text { Fac } \\
\text { Books Purchas }\end{array}$ & $\begin{array}{l}\text { ulty } \\
\text { ed }\end{array}$ & $\begin{array}{r}\text { Fiscal } 2017 \\
\text { Books Purc }\end{array}$ & $\begin{array}{l}\text { Faculty } \\
\text { chased }\end{array}$ & $\begin{array}{r}\text { Fiscal } 2018 \text { F } \\
\text { Books Purch }\end{array}$ & $\begin{array}{l}\text { aculty } \\
\text { nased }\end{array}$ \\
\hline Business School & 180 & 38 & & 66 & & 76 & \\
\hline Political Science and Criminal Justice & 123 & 16 & & 55 & & 52 & \\
\hline Psychology & 132 & 28 & & 59 & & 45 & \\
\hline Educational Leadership & 131 & 20 & & 51 & & 60 & \\
\hline Total & 566 & 102 & & 231 & & 233 & \\
\hline
\end{tabular}

ordering is skewed heavily in favor of the senior-level faculty members, and that more junior faculty members are submitting more e-book requests, which I neglected to capture three years ago. If it is the case that book orders are largely being submitted by senior faculty, then I need to develop a strategy to engage those who are more junior.

\section{THE BOOK-ORDERING PROCESS}

The focus for book ordering is our third-floor hard-copy collection, along with an e-book collection for my five areas of responsibility. USD's library uses a "jobber" known as the Yankee Book Peddlers (YBP) for its book ordering. YBP produces a weekly list online of the newly published academically oriented hard copy and e-books relevant to each discipline; their electronic list is e-mailed to me. I scale the list's contents back to ten fields to make everything easier to browse for my faculty members. The matrix I create is then exported into a spreadsheet that is copied and pasted into the body of an e-mail message sent to the faculty in each of my departments. Table 4 shows a portion of what I sent to the psychology department sometime in August 2018.

Faculty members with interest in anything on these weekly lists can e-mail their order requests directly to me. I then place the order for the book with YBP. This process helps me keep track of what faculty might be interested in various books and serves as an easy way to communicate with the seventy-five faculty members I liaise with.

Following receipt of any request, I input the information into a database I created using Microsoft Access (see table 5).

I have maintained separate Access files for each fiscal year since 2016, forming a data set for this study that ends with fiscal year 2018. A significant mistake I made starting in FY 2016 was failing to differentiate between orders for hard-copy and e-books. 


\section{RESULTS}

Since 2016, 566 books have been ordered by faculty members in my departments. I was disappointed with the total, which I expected would be much higher. The data breaks down by department and year (see table 6).

From the 566 book orders during this three-year span, I discovered that:

- 289 books (51 percent) were for senior faculty members who make up 41 percent of the faculty in my five departments.

- 85 books (15 percent) were for mid-level faculty members who make up 19 percent of the faculty in my five departments.

- 192 books (34 percent) were for junior faculty members who make up 40 percent of the faculty in my five departments.

These results pleasantly surprised me. Although it proved to be true that senior faculty members accounted for a higher percentage of total book orders (51 percent) than their representation on the faculty (41 percent), the difference of 10 percent is not dramatic. Similarly, more junior faculty members are "underperforming" in book orders compared to their representation on the faculty, but only by a difference of 4 percent in the case of mid-level faculty and 6 percent in the case of junior-level faculty. Arguably, these results are what one might anticipate given the difference seniority makes in terms of awareness of the literature and confidence about spending decisions.

One additional aspect of this study that initially interested me involves the so-called 80/20 rule. I work with seventy-five faculty members, so I was interested in whether approximately fifteen (or 20 percent) of them might account for 80 percent of the orders. The data indicates that my top fifteen "performers" generated 65 percent of book orders in my department (see table 7).

One significant trend in the data shows which faculty members do not engage in book ordering. Of those faculty members with whom I work, thirty-five of the seventy-five (or 47 percent) have not submitted any book orders over the past three years. This amounts to more than 50 percent of junior- and mid-level faculty members across the five departments (see table 8).

\section{CONCLUSIONS}

This study of faculty book ordering helped me to evaluate my efforts to enhance our monograph collection in the five departments with which I work. As a result, I was able to begin to quantify some frustrations or problems from the standpoint of marketing. Getting buy-in from the 47 percent of faculty members who have not requested any book

Table 7. Top fifteen book-ordering faculty, responsible for 65 percent of overall book ordering over the three-year period of 2016-2018

\begin{tabular}{llc}
\hline Faculty Member's & $\begin{array}{l}\text { Junior, Mid-Level } \\
\text { or Senior Faculty } \\
\text { Demartment }\end{array}$ & $\begin{array}{c}\text { Number of Books } \\
\text { Ordered from FY } \\
\text { 2016 through FY } \\
\text { Member }\end{array}$ \\
\hline Psychology & Senior & 58 \\
\hline Business & Middle & 33 \\
\hline $\begin{array}{l}\text { Educational } \\
\text { Leadership }\end{array}$ & Senior & 33 \\
\hline $\begin{array}{l}\text { Educational } \\
\text { Leadership }\end{array}$ & Senior & 31 \\
\hline Political Science & Senior & 26 \\
\hline Business & Senior & 22 \\
\hline Psychology & Senior & 22 \\
\hline Educational & Junior & 21 \\
Leadership & & 20 \\
\hline Political Science & Senior & 20 \\
\hline Business & Junior & 18 \\
\hline Political Science & Senior & 18 \\
\hline Psychology & Senior & 16 \\
\hline Business & Junior & 14 \\
\hline Business & Senior & \\
\hline $\begin{array}{l}\text { Educational } \\
\text { Leadership }\end{array}$ & Junior & \\
\hline & & \\
\hline
\end{tabular}

Table 8. Faculty members not engaged in book ordering

\begin{tabular}{lcccc}
\hline & $\begin{array}{c}\text { Total Faculty Not } \\
\text { Engaging in the } \\
\text { Ordering Process }\end{array}$ & $\begin{array}{c}\text { Senior Faculty Not } \\
\text { Engaging in the } \\
\text { Ordering Process }\end{array}$ & $\begin{array}{c}\text { Mid-Level Faculty } \\
\text { Not Engaging in the } \\
\text { Ordering Process }\end{array}$ & $\begin{array}{c}\text { Junior Level Faculty } \\
\text { Not Engaging in the } \\
\text { Ordering Process }\end{array}$ \\
\hline $\begin{array}{l}\text { Business School } \\
\text { Political Science and }\end{array}$ & 20 & 4 & 4 & 12 \\
Criminal Justice & 7 & 4 & 2 & 1 \\
\hline Psychology & 7 & 3 & - & 2 \\
\hline Educational Leadership & 1 & 1 & 8 & - \\
\hline Total & 35 & 12 & 15 \\
\hline
\end{tabular}




\section{MANAGEMENT}

purchases will be a challenge. I suspect that the worst thing I can do is to engage in "overkill" by sending more e-mail messages. My conclusion is that I need to engage in far more relationship building with the more junior faculty members but not solely the most junior. The data presented above shows that the underperformance rate of mid-level faculty is only two percentage points better than that of junior-level faculty.

I discussed this topic as part of a poster session at our recent state library conference. The feedback I received from a number of my counterparts was most helpful. Each talked about their own frustrations in dealing with departmental or teaching faculty, particularly new faculty, who are seemingly oblivious to the benefits of their university's library system. An academic library director suggested I make individual contact with faculty members who never respond to group e-mail messages anytime I come across something in their "departmental sphere," asking if they would like it ordered for the USD library. A counterpart from another institution felt that I should highlight by e-mail new acquisitions that have arrived relating to their department, which could generate more excitement.
With this new data and input, I clearly have some thinking and experimenting to do at the start of next semester!

\section{References}

1. See https://www.usd.edu/about-usd/usd-at-a-glance.

2. Kuo Hui-Min, "Surveying Faculty Book Selection in a Comprehensive University Library," Collection Building 19, no. 1 (January 2000): 27-35.

3. Larry Hardesty, "Book Selection for Undergraduate Libraries: A Study of Faculty Attitudes," Journal of Academic Librarianship 12, no. 1 (March 1986): 19-25.

4. Felix T. Chu, "Collaboration in a Loosely Coupled System: Librarian-Faculty Relations in Collection Development," Library E Information Science Research 17 (Spring 1995): 135-50; Felix T. Chu, "Librarian-Faculty Relations in Collection Development," Journal of Academic Librarianship 23 (January 1997): 15-20.

5. ALEPH was USD's online library catalog until May 2017.

6. University of South Dakota, Faculty Handbook and Resource Guide (Vermillion, South Dakota, 2017): 9-16.

7. Ron Zemke, Claire Raines, and Bob Filipczak, Generations at Work: Managing the Clash of Boomers, Gen Xers, and Gen Yers in the Workplace (New York: AMACOM, 2013), 61. 